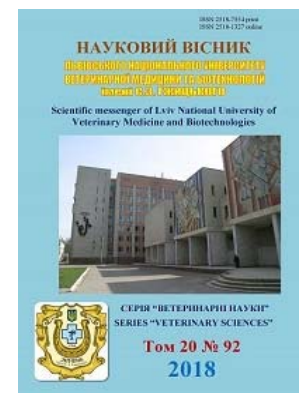

\author{
Науковий вісник Дьвівського національного університету \\ ветеринарної медицини та біотехнологій імені С.З. Гжицького
}

\author{
Scientific Messenger of Lviv National University \\ of Veterinary Medicine and Biotechnologies
}

UDC 636.2:576.89

\title{
Features of embryo and morphogenesis trichurise eggs of cattle in vitro
}

\author{
T.S. Shevchenko
}

Poltava State Agrarian Academy, Poltava, Ukraine

Article info

Received 29.10.2018

Received in revised form 27.11.2018

Accepted 28.11.2018

Poltava State Agrarian Academy, Skovorody Str., 1/3, Poltava, 36003, Ukraine.

Tel: +38-073-060-97-40

E-mail:sts-28.02@ukr.net
Shevchenko, T.S. (2018). Features of embryo and morphogenesis trichurise eggs of cattle in vitro. Scientific Messenger of Lviv National University of Veterinary Medicine and Biotechnologies, 20(92), 161-164. doi: 10.32718/nvlvet9233

One of the main factors hampering the development of livestock is the proliferation of a large number of diseases, both contagious and non-contagious etiology. Parasitic diseases of cattle and, in the first place, helminthiasis occupy a significant proportion of the diseases of contagious etiology. The dominant position among the helminthiasis of the digestive organs in ruminants is nematodosis of the gastrointestinal tract, in particular trichyrosis, the economic losses of which consist of a decrease in the productivity of animals due to the development of inflammatory processes in the thick intestine. Trihuris are geoellimits, which are localized predominantly in the blind and colon of the gastrointestinal tract. Females of the parasite lay eggs, which, with fecal animals, are released into the environment, where they are formed and reaches the invasive stage of the larva. Terms of preinvasive development depend on temperature. At a temperature of $30^{\circ}$ in the eggs of T. ovis, the larva is formed after 17 days, and at $13-17^{\circ}-$ after 118 days. At $10^{\circ}$ and below, the development of eggs is suspended, but they remain viable for several months. At temperatures above $38^{\circ}$ the eggs die. According to U. A. Magometbekova (1953), in eggs of T. skrjabini, which parasitized in sheep, at $25-30^{\circ}$ an invasive larva can be detected in 44-46 days after the eggs enter the environment. Eggs are bad for drying. The results of cultivation of eggs of T. skrjabini, the females of which parasitized in cattle, in vitro at a temperature of $27^{\circ}$ for 51 days are given. The features of embryo and morphogenesis of eggs of pathogens during cultivation were studied. From the thick intestine of young cattle, by the method of a complete helminthological section by K.I. Scriabin, sexually mature nematodes were isolated, from which female gonads received immature eggs that were cultivated. It was found that at temperatures of $27{ }^{\circ} \mathrm{C}$ eggs T. skrjabini, parasitized in the thick intestine of cattle, pass into the stage of invasive larvae from the 27th day and completely stop their development to 51 days. During the period of cultivation, the length of eggs and caps is increased by 2.0 and $20.0 \%$, the width of eggs and caps is reduced by 2.3 and $3.9 \%$, compared to the cultivars. Reduced egg shell thickness by the 27th day of cultivation (by 2.1\%) with a subsequent cessation of changes in this index.

Key words: Embryogenesis, morphogenesis, cultivation, eggs, trichurosis.

\section{Особливості ембріо- та морфогенезу ясць трихурисів врх in vitro}

\author{
Т.С. Шевченко
}

Полтавська державна аграрна академія, м. Полтава, Украӥна

Одним із головних факторів, які стримують розвиток скотарства, є розповсюдження значної кількості хвороб як заразної, так і незаразної етіологї. Серед хвороб заразної етіології значну питому вагу займають паразитарні хвороби великої рогатої худоби і насамперед - гельмінтози. Домінуюче становище серед гельмінтозів органів травлення у жуйних займають нематодози илунково-кишкового тракту, зокрема трихуроз, економічні збитки від якого починаються зі зниження продуктивності тварин внаслідок розвитку запальних процесів у товстому відділі кишечнику. Трихуриси - це геогельмінти, які локалізуються переважно в сліпій та ободовій кишках шлунково-кишкового тракту. Самки паразита відкладають яйця, які з фекаліями тварин виділяються у зовнішнє середовище, де в них формується і досягає інвазійної стадії личинка. Строки преінвазійного розвитку залежать від температури. При температурі $30^{\circ}$ в яйиях T. оvіs личинка формується через 17 днів, а при 13-17 ${ }^{\circ}$ - через 118 днів. 3а температури $10^{\circ}$ і нижче розвиток яєць призупиняється, але вони декілька місяців залишаються життєздатними. За температури вище $38^{\circ}$ яйчя гинуть. Згідно спостережень У.А. Магометбекова (1953), в яйиях T. skrjabini, які паразитували у овеиь, при 25-30 ${ }^{\circ}$ інвазійну личинку можна виявити через 44-46 днів після потрапляння яєць у зовнішнє середовище. Яйця погано переносять висуцування. У статті наведені результати культивування яєць T. skrjabini, самки яких паразитували у великої рогатої худоби, в умовах іп 
vitro при температурі $27^{\circ}$ протягом 51 доби. Вивчено особливості ембріо- та морфогенезу яєць збудників під час культивування. Із товстого відділу кишечнику молодняку великої рогатої худоби методом повного гельмінтологічного розтину за К.І. Скрябіним, були виділені статевозрілі нематоди, з гонад самок яких були отримані незрілі яйия, які були піддані культивуванню. Встановлено, щзо при температурі $27{ }^{\circ}$ С яйия T. skrjabini, щзо паразитують у товстому відділі кишечнику великої рогатої худоби, переходять в стадію інвазійної личинки з 27 - доби та повністю припиняють свій розвиток до 51 доби. За період культивування довжина яєиь та кришечок збільшується на 2,0 та 20,0\%, иирина яйчя та кришечки зменшується на 2,3 та 3,9\% проти показників до культивування. Визначено зменшення товщчини оболонки яєць до 27-го дня культивування (на 2,1\%) з подальщим припиненням змін ичього показника.

Ключові слова: ембріогенез, морфогенез, культивування, яйця, трихуроз.

\section{Вступ}

Актуальність теми: у сільськогосподарському виробництві молочному скотарству належить одне 3 провідних місць. Головним завданням розвитку молочного скотарства є збільшення виробництва молока і зростання економічної ефективності галузі на основі підвищення продуктивності великої рогатої худоби, зниження матеріальних, енергетичних і трудових витрат. Цими критеріями визначається сутність і цінність технологічного виробництва (Shamhalov, 2011).

На зниження молочної продуктивності тварин і збільшення матеріальних та енергетичних затрат на виробництво тваринницької продукції впливають паразитарні захворювання, зокрема трихуроз великої рогатої худоби (Boyko, 2012; Bajsarova and Ajshanov, 2017). Масовій інвазії великої рогатої худоби сприяє стійкість ясць збудників у зовнішньому середовищі, тривалість розвитку і збереження життєздатності яких значно відрізняються в різних природно-кліматичних умовах (Bisset et al., 1997; Gareev, 1980; Al-Albudi and Mosaab, 2017). Знання особливостей і термінів розвитку яєць збудників нематодозів є дуже важливим аспектом при вивченні гельмінтів, оскільки дає змогу підвищити ефективність проведення заходів 3 профілактики та боротьби гельмінтозними захворюваннями. Тому доцільним є детальніше вивчення трихурозу великої рогатої худоби в лісо-степовій зоні України, зокрема ембріо- та морфогенезу яєць збудників, що є визначальним для створення ефективних схем лікування та термінів проведення дегельмінтизації

Мета $i$ завдання досліджень. Метою досліджень стало вивчити зміни в морфології яєць трихурисів великої рогатої худоби та особливості ембріогенезу в умовах експериментального культивування. Завдання досліджень - стало провести експериментальне культивування яєць трихурисів, виділених із гонад самок паразитів, в умовах in vitro, до інвазійної стадії та дослідити зміни в довжині й ширині яйця, довжині та ширині кришечки, а також зміни товщини оболонки в процесі дозрівання яєць.

\section{Матеріал і методи досліджень}

Дослідження проводили в осінньо-зимовий період 2017 року на базі наукової лабораторії паразитології кафедри паразитології та ветеринарно-санітарної експертизи факультету ветеринарної медицини Полтавської державної аграрної академії.

В умовах сільськогосподарського приватного підприємства "РВД-Агро” Черкаського району було забито 20 голів молодняку ВРХ, із кишечнику яких, шляхом повного гельмінтологічного розтину за К.I. Скрябіним, були виділені та ідентифіковані до виду статевозрілі нематоди Trichuris skrjabini. Яйця паразитів отримали із гонад самок Т. skrjabini за методом Г.А. Котельникова і В.М. Хренова (1984) (Halat et al., 2004). Досліджено 100 яєць трихурисів.

Визначали морфологічні та біометричні параметри яєць трихурисів на різних стадіях їхнього розвитку. Яйця культивували до інвазійної стадії у термостаті за температури $27^{\circ} \mathrm{C}$ протягом 51 доби. Через кожні три доби культуру розглядали під мікроскопом (х 100, х 150). Кожний дослід проводили в трьох повторюваннях.

Біометрію виділених яєць $T$. skrjabini проводили iз застосуванням об'єкт-мікрометра, окуляр-мікрометра і мікроскопа при збільшенні х 100, х 400. Морфометричні параметри яєць трихурисів визначали з попереднім визначенням ціни поділки окуляр-мікрометра. Визначали форму, структуру, колір, характер поверхні оболонки, довжину, ширину яєць, довжину та ширину кришечок на полюсах, а також товщину оболонки. Мікрофотографування проводили за допомогою цифрової камери до мікроскопа MICROmed 3Mpix (China).

\section{Результати та їх обговорення}

До початку досліду всі яйця мали бочкоподібну форму з кришечками на полюсах, колір від світложовтого до коричневого, однорідну структуру та перебували на стадії протопласту. Під час культивування 20\% яєць припинили свій розвиток ще на стадії аморфної маси. На 3-тю добу 46\% яєць знаходилися на стадії протопласту, а 54\% містили 2 бластомери. На 6-й день експерименту 55\% яєць переходить в стадію 3-х і більше еластомерів, а на стадії 2-х еластомерів залишається 21\% яєць. Вже на 9-ту добу 3'являються перші яйця на стадії бобоподібного зародку (2\%) і 77\% залишається на стадії бластомерів. На 12 день культивування на стадії бобоподібного зародка вже було 9\% яєць, в стадії бластомерів залишалося $71 \%$ яєць трихурисів. На 15-ту добу культивування $60 \%$ яєць містили 3 і більше бластомери, 13\% яєць перебували у стадії бобоподібного зародка і вже 7\% яєць були на стадії пуголовка. На 18-ту добу на стадії бластомерів залишилося 24\% яєць, на 21-шу добу $5 \%$, на 24-ту добу - всього 2\% яєць. У стадії бобоподібного зародка на 18-ту добу вже було 42\%, на 21-шу добу - 37\%, на 24-ту добу - 32\% яєць. В стадії пуголовка на 18 добу було 7\% яєць, на 21 добу - 38\%, на 24-ту добу - 46\% яєць трихурисів. На 27 добу 
3'являється перше яйце 3 інвазійною личинкою (1\%), разом з тим 2\% яєць перебувають на стадії личинки, $51 \%$ - пуголовка та 25\% яєць ще в стадії бобоподібного зародка. На 36-ту добу досліду кількість яєць у фазі пуголовка зменшується до $41 \%$, тимчасом як $24 \%$ і $15 \%$ яєць перебуває на стадії личинки та рухливої личинки відповідно. На 45-ту добу кількість інвазійних яєць збільшується до 68\% і 12\% яєць залишається на стадії личинки. На 48 добу культивування 1\% яєць залишився на стадії личинки, а 79\% перейшли на стадію рухливої личинки. Всі 80\% дослідних яєць досягли інвазійної стадії на 51 день експерименту.

\section{Таблиця 1}

Розвиток яєць T. skrjabini в процесі ембріогенезу

\begin{tabular}{|c|c|c|c|c|c|c|c|c|}
\hline \multirow[b]{2}{*}{ Доба } & \multicolumn{8}{|c|}{ Стадія розвитку, $\mathrm{M} \pm \mathrm{m},(\mathrm{n}-100)$} \\
\hline & $\begin{array}{c}\text { Аморфної } \\
\text { маси }\end{array}$ & $\begin{array}{c}\text { 2-х бласто- } \\
\text { мерів }\end{array}$ & $\begin{array}{c}3 \text { і більше } \\
\text { бластомерів }\end{array}$ & $\begin{array}{c}\text { Бобоподібного } \\
\text { зародка }\end{array}$ & Пуголовка & Личинка & $\begin{array}{l}\text { Рухлива } \\
\text { личинка }\end{array}$ & $\begin{array}{c}\text { Припинення } \\
\text { розвитку }\end{array}$ \\
\hline 1 & $100 \pm 0$ & & & & & & & \\
\hline 3 & $45,66 \pm 0,83$ & $54,33 \pm 0,83$ & & & & & & \\
\hline 6 & $23,66 \pm 1,12$ & $21,0 \pm 0,76$ & $55,33 \pm 1,00$ & & & & & \\
\hline 9 & $20,33 \pm 0,83$ & $3,33 \pm 0,44$ & $74,33 \pm 0,91$ & $2,0 \pm 0$ & & & & \\
\hline 12 & $20,0 \pm 0,81$ & $2,0 \pm 0,57$ & $69,33 \pm 0,71$ & $8,66 \pm 0,62$ & & & & \\
\hline 15 & & & $60,0 \pm 0$ & $13,33 \pm 0,71$ & $6,66 \pm 0,71$ & & & $20,00 \pm 0,81$ \\
\hline 18 & & & $24,33 \pm 0,91$ & $42,00 \pm 0,82$ & $13,66 \pm 0,91$ & & & $20,00 \pm 0,81$ \\
\hline 21 & & & $5,00 \pm 0,57$ & $37,00 \pm 1,20$ & $38,00 \pm 1,07$ & & & $20,00 \pm 0,81$ \\
\hline 24 & & & $2,00 \pm 0,57$ & $31,66 \pm 0,71$ & $46,33 \pm 0,62$ & & & $20,00 \pm 0,81$ \\
\hline 27 & & & & $25,33 \pm 0,71$ & $51,33 \pm 0,62$ & $2,33 \pm 0,44$ & $1,00 \pm 0$ & $20,00 \pm 0,81$ \\
\hline 30 & & & & $22,0 \pm 0,76$ & $53,00 \pm 0,58$ & $3,33 \pm 0,44$ & $1,66 \pm 0,44$ & $20,00 \pm 0,81$ \\
\hline 33 & & & & $14,33 \pm 1,08$ & $58,66 \pm 0,83$ & $4,66 \pm 0,44$ & $2,33 \pm 0,44$ & $20,00 \pm 0,81$ \\
\hline 36 & & & & & $41,33 \pm 0,83$ & $23,66 \pm 0,71$ & $15,00 \pm 0,57$ & $20,00 \pm 0,81$ \\
\hline 39 & & & & & & $46,66 \pm 1,64$ & $33,33 \pm 1,43$ & $20,00 \pm 0,81$ \\
\hline 42 & & & & & & $32,66 \pm 1,01$ & $47,33 \pm 0,62$ & $20,00 \pm 0,81$ \\
\hline 45 & & & & & & $11,66 \pm 0,83$ & $68,33 \pm 0,91$ & $20,00 \pm 0,81$ \\
\hline 48 & & & & & & $1,33 \pm 0,44$ & $78,66 \pm 0,71$ & $20,00 \pm 0,81$ \\
\hline 51 & & & & & & & $80,00 \pm 0,82$ & $20,00 \pm 0,81$ \\
\hline
\end{tabular}

Таблиця 2

Морфометричні показники яєць T. skrjabini під час експериментального культивування

\begin{tabular}{crrrrr}
\hline Доба & Довжина яйця & Ширина яйця & Довжина кришечки & Ширина кришечки & Товщина оболонки \\
\hline 1 & $74,2 \pm 0,64$ & $38,2 \pm 0,44$ & $10,2 \pm 0,25$ & $12,7 \pm 0,42$ & $4,8 \pm 0,36$ \\
3 & $74,4 \pm 0,90$ & $38,1 \pm 0,31$ & $10,3 \pm 0,37$ & $12,7 \pm 0,37$ & $4,8 \pm 0,20$ \\
6 & $74,6 \pm 1,11$ & $38,1 \pm 0,48$ & $10,5 \pm 0,50$ & $12,6 \pm 0,45$ & $4,8 \pm 0,29$ \\
9 & $74,9 \pm 0,64$ & $38 \pm 0,26$ & $10,7 \pm 0,37$ & $12,6 \pm 0,45$ & $4,8 \pm 0,29$ \\
12 & $75 \pm 1,21$ & $38 \pm 0,54$ & $10,9 \pm 0,50$ & $12,6 \pm 0,40$ & $4,8 \pm 0,33$ \\
15 & $75,2 \pm 0,49$ & $37,9 \pm 0,28$ & $11,0 \pm 0,39$ & $12,6 \pm 0,43$ & $4,8 \pm 0,33$ \\
18 & $75,3 \pm 1,00$ & $37,9 \pm 0,23$ & $11,1 \pm 0,38$ & $12,5 \pm 0,17$ & $4,8 \pm 0,36$ \\
21 & $75,4 \pm 1,07$ & $37,9 \pm 0,46$ & $11,2 \pm 0,44$ & $12,5 \pm 0,34$ & $4,8 \pm 0,25$ \\
24 & $75,5 \pm 0,83$ & $37,8 \pm 0,51$ & $11,2 \pm 0,42^{*}$ & $12,4 \pm 0,34$ & $4,7 \pm 0,37$ \\
27 & $75,5 \pm 0,58$ & $37,8 \pm 0,33$ & $11,3 \pm 0,49$ & $12,4 \pm 0,40$ & $4,7 \pm 0,33$ \\
30 & $75,2 \pm 0,68$ & $37,8 \pm 0,65$ & $11,4 \pm 0,58$ & $12,4 \pm 0,27$ & $4,7 \pm 0,26$ \\
33 & $74,2 \pm 0,79$ & $37,7 \pm 0,54$ & $11,4 \pm 0,48^{*}$ & $12,3 \pm 0,21$ & $4,7 \pm 0,37$ \\
36 & $75,6 \pm 0,60$ & $37,5 \pm 0,37$ & $11,5 \pm 0,27^{* * *}$ & $12,3 \pm 0,21$ & $4,7 \pm 0,31$ \\
39 & $75,6 \pm 0,89$ & $37,2 \pm 0,51$ & $11,6 \pm 0,63^{*}$ & $12,2 \pm 0,42$ & $4,7 \pm 0,39$ \\
42 & $75,7 \pm 0,87$ & $37,2 \pm 0,51$ & $11,6 \pm 0,63^{*}$ & $12,2 \pm 0,39$ & $4,7 \pm 0,33$ \\
45 & $75,7 \pm 0,87$ & $37,3 \pm 0,52$ & $11,6 \pm 0,63^{*}$ & $12,2 \pm 0,42$ & $4,7 \pm 0,37$ \\
49 & $75,7 \pm 0,83$ & $37,3 \pm 0,58$ & $11,6 \pm 0,30^{* * *}$ & $12,2 \pm 0,25$ & $4,7 \pm 0,33$ \\
51 & $75,7 \pm 0,83$ & $37,3 \pm 0,47$ & $12,2 \pm 0,42^{* * *}$ & $12,2 \pm 0,29$ & $4,7 \pm 0,37$ \\
\hline
\end{tabular}

Примітки: ${ }^{*}-\mathrm{P}<0,05, * *-\mathrm{P}<0,01, * * *-\mathrm{P}<0,001-$ порівняно з показниками до культивування

Згідно з даними, поданими в таблиці 2, на 3-й день культивування відмічали збільшення довжини яйця на 0,3\% і довжини кришечки на 2,7 порівняно 3 показниками до культивування, та незначне зменшення ширини яйця на $0,3 \%$ порівняно $з$ початковими показниками. Довжина кришечки збільшилася на 1\%, а ширина кришечки та товщина оболонки яєць залишалися незмінними. На 6-ту добу відмічалося збільшення довжини яйця на $0,5 \%$, довжини кришечки на 2,9\% та зменшення ширини кришечки на 0,8\%. На 9-й день досліду яйця збільшилися в довжині на 0,9\%, збільшилася довжина кришечки на 2,9\%, ширина яєць зменшилася на 0,5\% порівняно 3 початковими показниками, а ширина кришечки та товщина оболонки залишалися незмінними. На 12-ту добу зміни відмічалися в довжині яйця та довжині кришечки, які збільшилися на 1 та 6,9\% відповідно. На 15-ту добу культивування довжина яйця та довжина кришечки про- 
довжує збільшуватися на 1,3 та на 7,8\% порівняно 3 даними до культивування, а ширина кришечки зменшилася на 0,8\%. На 18-ту добу довжина яйця продовжує збільшуватися на $1,5 \%$, довжина кришечки на $8,8 \%$, а ширина кришечок яєць зменшується на $1,6 \%$. На 21-шу добу зміни реєстрували в довжині яйця та кришечок, які збільшилися на 1,6 та 9,8\% порівняно з початковими показниками. На 24-ту добу експерименту зменшується товщина оболонки яйця на 2,1\% і до кінця культивування залишається незмінною. Довжина яєць достовірно збільшується на 1,8\% (P < 0,05), а ширина яєць та кришечки зменшується на 1 та 2,4\% відповідно. На 27-му добу продовжує збільшуватися довжина кришечки на $10,8 \%$, інші морфо-метричні показники залишаються незмінними. На 30-ту добу досліду довжина яйця зменшується на 0,4\% порівняно 3 показниками на 24-ту добу, а довжина кришечки збільшується на 11,8\% порівняно 3 початковими даними. На 33-тю добу яйця T. skrjabini в довжині ще зменшуються і набувають початкових показників, а також зменшується ширина яєць на 1,3\% та ширина кришечок на 3,1\%. До 36-ої доби довжина кришечки продовжує достовірно збільшуватися на 12,7\% (P < $0,001)$, довжина яйця знову збільшується майже на $2,0 \%$, а ширина яйця зменшилася майже на 2,0\% порівняно 3 даними до початку експерименту. На 39-ту добу зазнає змін ширина яйця, що зменшується на $2,6 \%$; ширина кришечки, яка зменшилася на 3,9\% порівняно $з$ показниками до культивування і до кінця експерименту більше не змінювалася; та збільшується довжина кришечки яєць на $13,7 \%$ (Р < 0,05). Наступні зміни в яйцях трихурисів відмічалися на 45-ту добу, ширина яких зменшилася на 2,3\% і до кінця експерименту залишилася в цьому діапазоні показників. На 51-шу добу культивування довжина яйця зросла на 2,0\% порівняно з показниками до початку культивування та довжина кришечки достовірно збільшилася майже на 20,0\% (P < 0,001).

\section{Висновки}

Проведеними дослідженнями встановлено, що при культивуванні яєць T. skrjabini, виділених з гонад самок, паразитуючих у великої рогатої худоби, в умоваx in vitro, за температури $27{ }^{\circ} \mathrm{C}$ перша інвазійна личинка з'являється вже на 27-му добу експерименту. Повне формування інвазійних личинок завершується до 51 доби.

На початку експерименту 20\% яєць припинили свій розвиток і залишилися на стадії аморфної маси. Довжина яєць та кришечок за період культивування збільшується на 2,0 та 20,0\% (Р <0,001), а їхня ширина зменшується на 2,3 та майже 4\% порівняно 3 показниками до культивування. Товщина оболонки яєць на 27-й день культивування зменшилася на 2,1\% і більше не змінювалася до кінця експерименту.

$\mathrm{y}$ перспективах подальших досліджень вивчити терапевтичну ефективність наявних на українському ринку ветеринарних антгельмінтиків проти збудника трихурозу великої рогатої худоби Trichuris skrjabini, зміни середньодобових приростів після лікування та дослідити зміни біохімічних і гематологічних показників крові після застосування лікарських антипаразитарних препаратів.

\section{References}

Al-Albudi, M., \& Mosaab, O. (2017). Prevalence of Gastrointestinal Nematodes of Farm Animals by Copro-Culture. Russian Journal of Parasitology, 2, 168-174. doi: 10.12737/20059.

Bajsarova, Z., \& Ajshanov, S. (2017). Zakonomernosti formirovanija parazitocenozov u krupnogo rogatogo skota na stojlovom i pastbishhnom rezhime soderzhanija. Rossijskij zhurnal parazitologii, 2, 131134. doi: 10.12737/20054 (in Russian).

Bisset, S.A., Vlassoff, A., West, C.J., \& Morrison, L. (1997). Epidemiology of nematodosis in Romney lambs selectively bred for resistance or susceptibility to nematode infection. Journal Veterinary Parasitology, 70(4). 255-269. doi: 10.1016/s03044017(96)01148-x.

Boiko, O.O. (2012). Sezonna dynamika chyselnosti nematod kopytnykh pryrodnoho zapovidnyka "DniprovskoOrilskyi”. Visnyk Dnipropetrovskoho universytetu biolohii ta veterynarnoi medytsyny, 3(2), 15-19. doi: 10.15421/021226 (in Ukrainian).

Gareev, A.G. (1980). Nekotorye voprosy jepizootologii trihocefaleza ovec v Bashkirskoj ASSR. Naukova dumka: Materialy konf. URNOP (in Russian).

Halat, V.F., Berezovskyi, A.V., Prus, M.P., \& Soroka, N.M. (2004). Parazytolohiia ta invaziini khvoroby tvaryn. Praktykum, 13 (in Ukrainian).

Magometbekov, U.A. (1953). Biologija nematody Trichocephalus skrjabini (Baskakow, 1924) i izuchenie nekotoryh voprosov jepizootologii trihocefaleza ovec v uslovijah Dagestana. Tr. GELAN SSSR, 8, 32-35 (in Russian).

Shamhalov, M.V. (2011). Trihocefalez ovec i koz v Prikaspijskom regione (jepizootologija i biologija vozbuditelej) i sovershenstvovanie mer bor'by. Avtoref. dis. kan. vet. nauk: 03.02.11. 155 (in Russian).

Yefremov, A. (2016). Osobennosti gel'mintozov u krupnogo rogatogo skota i ovec v Kaliningradskoj oblasti. Russkij zhurnal parazitologii, 3, 319-324. doi: 10.12737/2165 (in Russian). 